\title{
Legal Argumentation and the Normativity of Legal Norms
}

\section{Argumentación jurídica y normatividad de las normas jurídicas}

\author{
Carlos Bernal ${ }^{1}$ \\ Macquarie Law School, Macquarie University, Sydney, Australia \\ carlos.bernal-pulido@mq.edu.au
}

Received: 12-08-2011 Accepted: 3-12-2011

\begin{abstract}
Legal argumentation has differing relations with the concept of normativity. On the one hand, normativity plays an important role in legal argumentation. This is because legal norms are elements of the arguments which go together to make up legal discourse. On the other hand, legal argumentation also plays a relevant role in grounding the normativity of legal norms. The normativity of legal norms is not only based on authority, but also on correctness, and correctness is achieved, at least in part, by compliance to rules governing legal argumentation. The aim of this paper is to analyse the most significant relationships between normativity and legal argumentation. To achieve this aim, the paper will consider four aspects: the normativity of the different kinds of legal norms, the rules of legal argumentation, the role played by the rules of legal argumentation in grounding the normativity of legal norms, and the role played by legal norms in legal argumentation.
\end{abstract}

Keywords: Normativity, Legal Rules, Legal Principles, Legal Norms, Legal Reasoning.

Resumen: La argumentación jurídica tiene distintos vínculos con el concepto de normatividad. Por un lado, la normatividad juega un papel importante en la argumentación jurídica. Esto se debe a que las normas jurídicas son elementos de los argumentos que estructuran el discurso jurídico. Por otra parte, la argumentación jurídica también juega un papel relevante en la fundamentación de la normatividad de las normas jurídicas. La normatividad de las normas jurídicas no sólo está basada en la autoridad, sino también en la corrección, y la corrección es alcanzada, al menos en

${ }^{1}$ The author thanks Eveline Feteris, Stanley Paulson, and an anonymous reviewer of Cogency for valuable feedback. 
parte, por medio del respeto de las reglas que gobiernan la argumentación jurídica. El objetivo de este trabajo es analizar las relaciones más significativas entre el concepto de normatividad y la argumentación jurídica. Para alcanzar este fin, el trabajo considerará cuatro aspectos: la normatividad de los distintos tipos de normas jurídicas, las reglas de la argumentación jurídica, el papel que juegan las reglas de la argumentación jurídica en la fundamentación de la normatividad de las normas jurídicas, y el papel que juegan por las normas jurídicas en la argumentación jurídica.

Palabras clave: Normatividad, reglas jurídicas, principios jurídicos, normas jurídicas, razonamiento jurídico.

\section{Introduction}

Legal argumentation has differing relations with the concept of normativity. On the one hand, normativity plays an important role in legal argumentation. This is because legal norms are elements of the arguments which go together to make up legal discourse. On the other hand, legal argumentation also plays a relevant role in grounding the normativity of legal norms. The normativity of legal norms is not only based on authority, but also on correctness, and correctness is achieved, at least in part, by compliance to rules governing legal argumentation.

The aim of this paper is to analyse the most significant relationships between normativity and legal argumentation. To achieve this aim, the paper will consider four aspects: the normativity of the different kinds of legal norms, the rules of legal argumentation, the role played by the rules of legal argumentation in grounding the normativity of legal norms, and the role played by legal norms in legal argumentation. The main claim that I would like to endorse here is that compliance with rules governing correct legal argumentation provides a foundation for the normativity of the primary and secondary norms of law. This paper aims to explain how this foundation is provided.

\section{The Normativity of Different Types of Legal Norms}

Various concepts of normativity have been stated throughout the history of philosophy and general jurisprudence. This is not hardly surprising if 
it is remembered that the concept of normativity designates the "evaluative or prescriptive" property of a statement (Hare, 1972, p. 1). Statements which boast this property and which contrast with factual statements are relevant to law, ethics and religious orders, and also to theories concerning themselves with these orders. There are strong debates between the many different accounts of normativity endorsed in these fields. ${ }^{2}$

With reference to law, the concept of normativity is the subject of interesting discussions concerning, among other things, how to understand the normativity of law and whether the law bears a special kind of normativity that is different from the normativity of moral norms ${ }^{3}$. For the present purposes, the relevant question is what the normativity of legal norms consists of. It should be pointed out that law is made up of various types of legal norms, and that the normativity of each one of these types of norms boasts certain individual properties. Two typologies of norms need to be considered for the present analysis. There is a connection between these two typologies, which gives rise to four types of normativity. Every one of these four types of normativity has a particular relationship with the rules governing legal argumentation. The first typology is the well-known differentiation between rules and principles; the second one is the Kelsenian distinction between primary and secondary norms.

The differentiation between rules and principles gives rise to two types of normativity: the normativity of rules, and the normativity of principles. The normativity of rules is an all-or-nothing affair. Rules apply in their entirety or they do not apply at all for resolving a specific case. If the de facto assumption envisaged in the rule has been proven, the judge should apply it in full. If, on the other hand, the de facto assumption envisaged in the rule is not verified, or despite the fact that it has been proven, an exception stipulated in it occurs as well, the judge should rule out the idea of applying it (Dworkin, 2000, p. 14). The normativity of principles, meanwhile, is a prima facie normativity (Ross 1930, p. 19; Hare, 1981, p. 27; Searle 1978, p. 84). As Alexy maintains, principles are "requirements to be optimized" with prima facie validity, which order their content to be realised to the greatest extent possible, as far as legal and factual possibilities are

${ }^{2}$ On these debates in ethics, see Korsgaard (1996).

${ }^{3}$ On the normativity of law, see Bertea (2009). 
concerned. The range of legal possibilities is determined by the opposing principles. While rules are definitive commands which apply by means of subsumption, principles are prima facie requirements which are applied by means of balancing (Alexy, 2002, p. 47).

The difference between primary and secondary legal norms also gives rise to two types of normativity. This is a distinction stated by Hans Kelsen. According to Kelsen, a primary norm gives the judge the power to impose the legal consequence, once the de facto assumption has been proven. A secondary norm, on the other hand, states the action that should be taken in order to prevent the legal consequence ${ }^{4}$. It is arguable in Kelsen's doctrine whether the secondary norm is addressed to the subject or whether it is a mere reflection of the primary norm (Bernal, 2004, p. 117). It is nevertheless true that these two types of norms are endowed with a different type of normativity. The normativity of primary norms is one that can be called weak (Paulson, 2005, p. 191). Kelsen referred to this meaning of normativity when he wondered what the specific normativity of law (Gesetzlichkeit des Rechts) consisted of. According to Kelsen, "imputation is recognised in the Pure Theory of Law as the particular lawfulness, the autonomy, of the law" (Kelsen, 1996, p. 23). This normativity consists in the power of the judge to impute the legal consequence. There is a strong normativity concept alongside this weak one. The strong concept could characterise the normativity of secondary norms better ${ }^{5}$. Joseph Raz alludes to this concept when he says that "aspects of the world are normative in as much as they or their existence constitute reasons for persons, that is, grounds which make

${ }^{4}$ I refer here to the classification into primary and secondary norms according to Kelsen, and not to the differentiation between primary and secondary rules, as stated by Hart. According to Kelsen: "Thus, the norm that establishes sanction-avoiding behaviour -behaviour the legal system aims to bring about- is a legal norm only on the presupposition that it is saying something (in abbreviated form for the sake of convenience) that the reconstructed legal norm alone states fully and correctly: given as condition, behaviour opposite to that which the norm establishes as sanction-avoiding, then a coercive act is to be forthcoming as consequence. This reconstructed legal norm is the legal norm in its primary form. The norm establishing sanction-avoiding behaviour can only be regarded, then, as a secondary legal norm" (Kelsen , 1996, p. 30).

${ }^{5}$ Despite his tendency to consider that the weak thesis of normativity applies to all law, even Kelsen himself appears to defend the strong thesis on occasions, when he states that legal norms are mandates drawn up in a categorical, imperative form, and that they are addressed to the legal subject via a secondary norm. See: Paulson 1998, p. 60. 
certain beliefs, moods, emotions, intentions or actions appropriate or inappropriate" (Raz, 1999, p. 67). Applying this concept to law would justify the legal obligation of the subject (Paulson, 2005, p. 191). The secondary norms are addressed to the subjects of law and they provide them with reasons for actions according to the law.

It has to be recognised that the classification into primary and secondary normativity has so far been carried out more with respect to rules. Kelsen's developments referred to norms which had a hypothetical, conditional structure and the properties of rules. It should nevertheless be pointed out that principles - and their normativity - can also be characterised as primary and secondary. Secondary principles have the structure $\mathrm{COx}$, in which the ' $\mathrm{C}$ ' stands for a command, and 'O' for optimization. These principles command the addressees of the principle to optimise the object of the principle (for example, Article 20 in the Spanish constitution - which guarantees the right to privacy - establishes a principle which orders, amongst other things, an employer to optimise a worker's privacy when using e-mail at his place of work). ${ }^{6}$ This optimisation requirement could be called the strong normativity of principles. It is addressed to every public or private subject of the principle, since principles - especially when they are constitutional rights - are binding on all public and private powers.

Alongside this dimension, principles also have a weak normativity. This normativity is adressed to the judge, and becomes effective at the moment the principle is applied. This normativity is explicit in the norm governing

${ }^{6}$ The Article 20 of the Spanish Constitution states that: '1. The following rights are recognised and protected: a) the right to freely express and disseminate thoughts, ideas and opinions trough words, in writing or by any other means of communication; b) the right to literary, artistic, scientific and technical production and creation; c) the right to academic freedom; d) the right to freely communicate or receive accurate information by any means of dissemination whatsoever. The law shall regulate the right to invoke personal conscience and professional secrecy in the exercise of these freedoms. 2. The exercise of these rights may not be restricted by any form of prior censorship. 3. The law shall regulate the organisation and parliamentary control of the social communications media under the control of the State or any public agency and shall guarantee access to such media to the main social and political groups, respecting the pluralism of society and of the various languages of Spain. 4. These freedoms are limited by respect for the rights recognised in this Title, by the legal provisions implementing it, and especially by the right to honour, to privacy, to personal reputation and to the protection of youth and childhood. 5 . The confiscation of publications and recordings and other information media may only be carried out by means of a court order.' 
the power to carry out a balancing exercise, or to be more precise, to apply the principle of proportionality and thus determine the maximum measure possible where the principle should be realised, taking into consideration the legal and factual reasons against it. In the example, Article 18 in the Spanish constitution gives the judge the power to balance the principle of protecting privacy against other relevant principles in a specific case, for instance protecting freedom of enterprise on the part of the employer.

The combination of these four types of normativity can be shown in a table.

$\begin{array}{lll} & \text { Strong Normativity } & \text { Weak Normativity } \\ \text { Rules } & \text { Command to do or not do } \mathrm{x} & \text { Power to impose the penalty } \\ \text { Principles } & \text { Requirement to optimise } \mathrm{x} & \text { Power to balance }\end{array}$

\section{A Concept of Legal Argumentation}

Secondly, the concept of legal argumentation needs to be specified. Legal argumentation can be defined as an interlocution or dialogue exercise between everyone involved in legal practice. As Feteris says, someone who presents a legal thesis is expected to put forth arguments to support it' (Feteris 1999, p. 1). Whether or not a thesis ought to be accepted and adopted as the solution for a practical question will depend on the extent to which these arguments are right. Legal argumentation is thus a practical activity, one which attempts to answer the practical question par excellence in concrete cases: what ought to be done? Legal argumentation sets out to ground a right answer to this question. However, because of the many conceptions of the good existing in every society, and because of the existence of moral disagreements, no attempt can be made to achieve a right answer by deriving it from a single system of values that is coherent in itself, rather by following certain rules of procedure which make legal argumentation rational. It is very true that adhering to these rules of procedure offers no guarantee that a single right answer will be arrived at in each case. However, if these rules of procedure are broken, it is indeed a serious sign of a lack of correctness in the answer to a case or the justification of it.

This explains why the main activity of legal argumentation theorists 
has been to create legal argumentation models which make the rules explicit for developing a rational legal argumentation (Atienza, 1991, p. 1). No single catalogue of rationality rules for legal argumentation exists in legal theory. This is one thing that has led to the most intricate of doctrinal controversies (Tugendhat, 1980, p. 1; Neumann 1986, p. 94). All in all, the best known rules, and the ones most widely accepted by doctrine, are those relating to (1) clarity and conceptual consistency, (2) normative consistency, (3) saturation, (4) adhering to deductive logic, (5) adhering to argumentation burdens, (6) honesty, (7) argumentation consistency, and (8) coherence. According to these rules, the more a legal argumentation is developed through arguments (1) which boast conceptual (Alexy, 1996, p. 344) and linguistic clarity and consistency (Alexy, 1989, p. 185; Aarnio, 1987, p. 254), (2) which can also justify the same interpretative results when they are applied to the same assumptions (Peczenik, 1983, p. 189), (3) which are complete - in other words, which contain all the premises belonging to them (Alexy, 1989, p. 236), (4) which adhere to deductive logic (Atienza, 1987, p. 193), (5) which adhere to argumentation burdens, (6) which correspond to the real thoughts of those who put them forward, (7) which have no internal contradictions (MacCormick, 1984, p. 43), and (8) which are supported by general rules or principles, the more rational it will be (Alexy, 1989; Peczenik, 1983, p. 115; Baum, 1984, p. 355; and Alexy, 1990, p. 97).

\section{Legal Argumentation in Normativity}

These legal argumentation rules play a leading role when it comes to grounding the normativity of primary rules (4.1) and primary principles (4.2) at the time of their application.

\subsection{Legal Argumentation and Primary Rules}

Firstly, the exercising of the judicial powers established in primary rules should not depend on the will or discretion of the judge, but rather should be the result of a correct legal argumentation. These powers are exercised by means of subsumption, the simplest structure of which is as follows: 

Major Premise:
(1) (x) (Tx $\rightarrow$ PRx)
Minor Premise:
(2) $\mathrm{Ta}$
Conclusion:
(3) PRa (1) (2) ${ }^{7}$

This structure expresses the step from the primary rule (1) to the individual norm (3), and is made up of the following elements: (1) the primary rule, consisting of a de facto assumption (Tx), the imputation link $(\rightarrow)$ which symbolises the power (P) the judge has been given to impute the legal consequence ( $\mathrm{Rx}$ ) if the de facto assumption (T) has been proven, and also the aforementioned legal consequence; (2) the minor premise (Ta), in other words, the subsumptive judgement according to which, fact (a), the individual example of facts in general (x), meets the conditions established by the de facto assumption (Tx) of rule (1); and the individual rule of competence (PRa), according to which, the judge is given the power to attribute legal consequence (R) to fact (a).

Legal argumentation rules perform a double function in this structure. Firstly, the very subsumption structure establishes an argumentation process which respects the rules of deductive logic. Secondly, the rules of rationality in legal argumentation should be applied in order to determine the major and minor premises of the subsumption. Identifying the primary rule which takes the place of the major premise is thus the result of a process whereby provisions are interpreted in the sources of law. Adhering to the rules of clarity, consistency and coherence is not only a limit and an orientation criterion merely for finding the normative meaning of the provisions which are relevant to the case; it is also useful for resolving contradictions or inconsistencies between various primary rules which are valid at one and the same time. Coherence rules are essential for resolving normative contradictions or inconsistencies. Clarity, consistency, coherence and saturation rules should moreover act as guide when evidence is being examined which leads to establishing whether fact (a) has been proven, and, in particular, to the formulation of the subsumptive statement (Ta). Viewed rationally, reducing the possible lack of determination in the primary rule is not something that should be left to the discretion of the judge,

${ }^{7}$ See, on this formula as a logical formula for the internal justification of jurisdictional decisions in general: Alexy, 1995, p. 20. 
but rather should be the product of a reasoning compliant with the rules of legal argumentation.

It is clear from the institutional viewpoint that determining the major and minor premises of the subsumption depends on the judge exercising his authority. However, this exercising of authority will only be considered correct from a critical perspective if the judge also adheres to the rules of legal argumentation.

\subsection{Legal Argumentation and Primary Principles}

Legal argumentation rules should likewise serve as guide for applying primary principles through balancing, or more extensively, through the principle of proportionality. The primary normativity of principles gives the judge the power to apply the principle of proportionality. This principle is a linked group of three sub-principles: suitability, necessity and proportionality in the strict sense of the word. Each of these sub-principles expresses a requirement which every interference in a principle should meet, if it is to be legally legitimate. These requirements can be summarised in the following terms (Bernal, 2007, p. 797; Alexy, 2002, p. 66).

According to the suitability sub-principle, every interference with a legal principle should be adequate and suitable for contributing to the realisation of another legal principle.

According to the necessity sub-principle, every interference measure with a principle should be the most benign, with respect to the principle which is being interfered with, of all measures which are at least equally suitable for helping to achieve the proposed goal.

Finally, the principle of proportionality in the strict sense of the word establishes that the importance of the goals sought by any interference with a principle should bear a corresponding relation to the meaning of the principle which is being interfered with.

As with subsumption, legal argumentation rules determine the very structure of the principle of proportionality. If this principle is observed closely, it will be seen to have a precise argumentation structure, consisting of various burdens of argumentation, a structure that are free of contradiction, which makes it clear what factual and normative variables are relevant for applying the principles at stake. Factual variables are expressed 
in the sub-principles of suitability and necessity, and also in the balancing exercise, when this determines the extent of factual interference between the principles which are relevant to the case. Normative variables, meanwhile, appear when the weight of the principles is being determined in the balancing exercise.

Using saturated, consistent and coherent chains of arguments will allow each variable to be given a correct answer. These chains will possibly lead in some cases to a single correct answer for each variable. In other cases, however, the only correct answer will be that there is no correct answer. In these cases, even from the point of view of correctness, the judge will have an irreducible margin of discretion

\section{Normativity in Legal Argumentation}

Finally, it is necessary to take into account the effect of normativity on legal argumentation. The strong normativity of secondary rules and principles has a bearing on subsumption and on balancing. In a legal system, this normativity not only means that secondary rules and principles constitute reasons for actions to their addressees which pre-empt other types of reasons, it also implies that together with the power to subsume and to balance, primary rules likewise impose a duty on the judge to impute the legal consequence, assuming that the de facto assumption has been proven, while primary principles impose a duty on him to resolve the case in the manner established in the principle which prevails in the balancing exercise. This duty expresses the special weight that normativity places on rules and principles, in comparison with other types of general, practical arguments which interfere with both the subsumption and the balancing exercise.

As far as subsumption is concerned, this duty which expresses the normativity of rules means that their argumentation structure varies, in the manner stated below.
Major premise:
(1) $(\mathrm{x})(\mathrm{Tx} \rightarrow \mathrm{ORx})$
Minor Premise:
(2) $\mathrm{Ta}$
Conclusion:
(3) ORa (1), (2) 
In the major premise, the judiciary has the power to impute the legal consequence $(\rightarrow \mathrm{Rx})$ and also is commanded to impute it $(\rightarrow \mathrm{ORx})$. This command means that when the judge exercises this power, she should preempt other types of reasons which result in a consequence other than (Rx) being arrived at. The primary rule is thus a reason which rules out other types of general practical arguments.

Something similar happens with balancing. The principles which come together in the structure of balancing bear also the normativity of reasons for action This is nevertheless not a definitive normativity, as is the case with rules, but rather just a prima facie normativity. Firstly, this normativity prevents the judge from disregarding a principle in a balancing exercise in a case which has at least a semantic property that enables it to be connected with this principle. Thus, if a specific case has a semantic property which links it to principle $P 1$ and a semantic property which links it to principle $P_{2}$, and the legal solutions deriving from $P_{1}$ and $P_{2}$ are incompatible with each other, the judge must necessarily establish whether $P 1$ should take precedence over $P_{2}$ in case (C), or vice versa: that is, if $P_{1} P_{P} 2$ or $P 2 P P 1$. In addition, and secondly, the prima facie normativity of the principle which has taken precedence in the balancing exercise forces the judge to resolve the case in the manner established by that principle. Thus, for example, if $P 1$ should have precedence, the judge should extract an ascribed norm from the balancing exercise which has the structure of a rule: (x) (Tx $\rightarrow$ ORx). In this structure, $T x$ is the de facto assumption consisting of the properties that are relevant in the specific case, and ORx expresses the command to impute the consequences established under principle $P 1^{8}$.

\section{Conclusions}

The preceding analysis leads to the following conclusions:

The combination of typologies of legal norms that was taken into ac-

${ }^{8}$ This is called by Alexy "Law of Competing Principles". According to this rule: "The circumstances under which one principle takes precedence over another constitute the conditions of a rule which has the same legal consequences as the principle taking precedence". See Alexy, 2002, p. 54; Alexy, 1995, p. 46. 
count here, namely, the distinction between rules and principles, on the one hand, and primary and secondary norms (endowed with a weak and a strong normativity, respectively), on the other, gives rise to four types of normativity of legal norms. Primary rules have a weak normativity. They empower the judge to impose the legal consequence foreseen in the rule if the de facto assumption of it has been proven. Secondary rules have a strong normativity. They command legal subjects to perform or not to perform a type of action. Primary principles have a weak normativity. They empower the judge to balance principles in collision. Finally, secondary principles have a strong normativity. They require their addressees to optimise their object (a right or a common good).

The rules governing legal argumentation concerning clarity and conceptual consistency, normative consistency, saturation, adhering to deductive logic, adhering to argumentation burdens, honesty, argumentation consistency, and coherence play a leading role when it comes to grounding the normativity of primary rules and primary principles at the time of their application. First, the exercising of the judicial powers established in primary rules should not depend on the will or discretion of the judge, but rather should be the result of a correct legal argumentation. These powers are exercised by means of subsumption. While the very subsumption structure establishes an argumentation process which respects the rules of deductive logic, the rules of rationality in legal argumentation should be applied in order to determine the premises at stake in the subsumption. Second, the rules of legal argumentation should likewise serve as guide for applying primary principles through balancing, or more extensively, through the principle of proportionality. As with subsumption, legal argumentation rules determine the very structure of the principle of proportionality. In addition, using saturated, consistent and coherent chains of premises will allow avoiding some incorrect results in the application of this principle.

Finally, the strong normativity of legal norms displays also an effect upon legal argumentation. The strong normativity of secondary rules and principles has a bearing on subsumption and on balancing. In a legal system, this normativity not only means that secondary rules and principles constitute reasons for actions to their addressees which pre-empt other types of reasons, it also implies that together with the power to subsume and to balance, primary rules likewise impose a duty on the judge to impute 
the legal consequence, assuming that the de facto assumption has been proven, while primary principles impose a duty on him to resolve the case in the manner established in the principle which prevails in the balancing exercise. This duty expresses the special weight that normativity places on rules and principles, in comparison with other types of general, practical arguments which interfere with both the subsumption and the balancing exercise.

\section{Works Cited}

Aarnio, A. The rational as reasonable: A treatise on legal justification. Dordrecht: Reidel, 1987.

Alexy, R. A Theory of Legal Argumentation. The Theory of Rational Discourse as Theory of Legal Justification. Oxford: Oxford University Press, 1989.

Alexy, R. "Die logische Analyse juristischer Entscheidungen." In Alexy, R., Recht, Vernunft, Diskurs. zur Rechtsphilosophie (pp.15-51). Frankfurt: Suhrkamp, 1995.

Alexy, R. "Juristische Begründung, System und Kohärenz." In Behrends, O., Diesselhorst, M. and Dreier, R., Rechtsdogmatik und Praktische Vernunft. Symposion zum 80. Geburstag von F. Wieacker (pp. 97-120). Göttingen: Vondenhoeck \& Ruprecht, 1990.

Alexy, R. "Grundgesetz und Diskurstheorie." In Brugger, W. (Ed.), Legitimation des Grundgesetzes aus Sicht von Rechtsphilosophie und Gesellschafstheorie (pp. 344-360). Baden: Nomos, 1996.

Alexy, R. A Theory of Constitutional Rights. Oxford: Oxford University Press, 2002.

Alexy, R. and Peczenik, A. "The Concept of Coherence and Its Significance for Discoursive Rationality." Ratio Juris 1 (1990): 115-147.

Atienza, M. "Para una razonable definición de razonable." Doxa 4 (1987): 189-202. Atienza, M. Las razones del derecho. Teorías de la argumentación jurídica. Madrid: Centro de Estudios Constitucionales, 1991.

Baum, B. "The Role of Coherence in Legal Reasoning." Law and Philosophy 3 (1984): 355-374.

Bernal, C. "Las normas de competencia en la Teoría Pura del Derecho de Kelsen.” En Villar, L. (Ed.), Hans Kelsen 1881-1973 (pp. 117-137). Bogotá: Universidad Externado de Colombia, 2004.

Bernal, C. El principio de proporcionalidad y los derechos fundamentales. Madrid: Centro de Estudios Políticos y Constitucionales, 2007.

Bertea, S. The Normative Claim of Law. Oxford and Portland (Oregon): Hart, 2009. 
Dworkin, R. Taking Rights Seriously. London: Duckworth, 2000.

Feteris, E. Fundamentals of Legal Argumentation. A Survey of Theories on the Justification of Judicial Decisions. Dordrecht: Kluwer, 1999.

Hare, R. The Language of Morals. Oxford: Clarendon Press, 1972.

Hare, R. Moral Thinking. Its Levels, Method and Point. Oxford: Clarendon Press, 1981.

Kelsen, H. Introduction to the Problems of Legal Theory. Trans. Bonnie Litschewski Paulson and Stanley L. Paulson. Oxford: Clarendon Press, 1996.

Korsgaard, C. The Sources of Normativity. Cambridge: Cambridge University Press, 1996.

MacCormick, N. “Coherence in legal justification.” In Krawietz, W. et al (eds.), Theorie der Normen. Festgabe für Ota Weinberger zum 65. Geburstag (pp. 43-63). Berlin: Duncker \& Humblot, 1984.

Neumann, U. Juristische Argumentationslehre. Darmstadt: Wissenschaftliche Buchgesellschaft, 1986.

Paulson, S. “An Empowerment Theory of Legal Norms.” Ratio Juris 1 (1998): 58-72.

Paulson, S. "Zwei radikale Objektivierungsprogramme in der Rechtslehre Hans Kelsens." In Paulson, S. and Stolleis, M. (eds.), Hans Kelsen, Staatsrechtslehrer und Rechtstheoretiker des 20. Jahrhunderts (pp. 191-220). Tuebingen: Mohr Siebeck, 2005.

Peczenik, A. Grundlagen der juristischen Argumentation. Viena: Sprinder, 1983.

Raz, J. Engaging Reason. On the Theory of Value and Action. Oxford: Oxford University Press, 1999.

Ross, W. The Right and the Good. Oxford: Clarendon Press, 1930.

Searle, J. "Prima Facie Obligations." In Raz, J. (Ed.), Practical Reasoning (pp. 84-90). Oxford: Oxford University Press, 1978.

Tugendhat, E. "Zur Entwicklung von moralischen Begründungsstrukturen im modernen Recht.” ARSP Beiheft 14 (1980): 1-20. 